〔症例報告〕

\title{
当教室で経験した強酸による化学熱傷： 産業医学的側面よりの検討
}

織茂 弘志, 山元 修, 小林 美和, 安田 浩

産業医科大学医学部 皮膚科学教室

要旨：平成12年 6 月, 当教室では強酸による化学熱傷を 2 例経験した。症例 1 は 44 歳の男性. 化学工場勤務中，防護マスクをしていたにもかかわらず，その隙 間より硝酸が侵入し，顔面に化学熱傷を受傷した。また，作業衣を通して右 上腕から肩甲部および両下腿から大腿前面にも被酸した。症例 2 は26歳の男 性. 化学工場勤務中，濃硫酸を雨前腕部に浴び，II度の化学熱傷を受傷した。 いずれの例も酸をホースにより充填している作業中に，不慮の事故で酸に曝 露している．両者ともマニュアルどおり15分以上の洗浄をし，重大な機能障 害を残すことなく軽快したが，一部深達性の損傷部位も認めた。さらなる安 全対策のために，産業医学的側面より検討を行った。今回の曝露事故を教訓

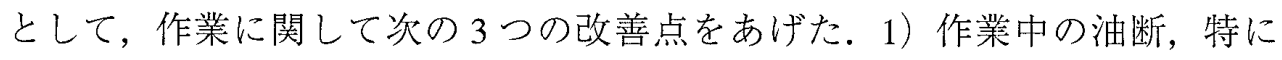
ベテランに多い慣れに伴う強酸の危険性の軽視に対しては，再教育あるいは 啓蒙活動が必要である．2）主な受傷部位以外にも，被酸部位の見逃しの可 能性があることに対しては，保護衣を脱ぎ，全身シャワーを浴びることを钬 めた．3）保護マスクをしていたにもかかわらず暴露したことに対しては， 保護マスクの改良を提案した。また，強酸曝露時の黄色痂皮を診たときは， 過小評価することなく，深達性潰場の存在を念頭におくべきであることを反 省した，事故防止のため，より質の高い安全対策が望まれる。

（2000年 11 月 15 日 受付，2001年 1 月 30 日 受理）

\section{はじめに}

化学物質が直接皮膚や粘膜に接触して，急 性に組織を障害した状態を一般的に化学熱傷 という。酸による障害は, 水素イオンが組織 蛋白と結合し acid-albuminate を作り, 組織を 脱水させ，凝固壊死をきたすためである [1]. この反応は, 強酸では深部まで達し腐食的に, 弱酸では表層にとどまり収斂的に作用する。 酸は一般的に乾性の痂皮を形成し, それが組 織へのそれ以上の酸の接触を妨げるために，
アルカリに比べると深達性は少ないといわれ ているが，重篤な障害を被る可能性がある点 では，アルカリと何ら変わるところはない。 今回我々は，硝酸抒よび硫酸による化学熱 傷を経験したのでここに報告し，主として産 業医学的見地より検討を加えた。

\section{症例}

症例 $1: 44$ 歳, 男性.

化学工場勤務（従業員約1500名）.

平成 12 年 6 月某日媣夜 0 時 30 分頃, 濾過水 


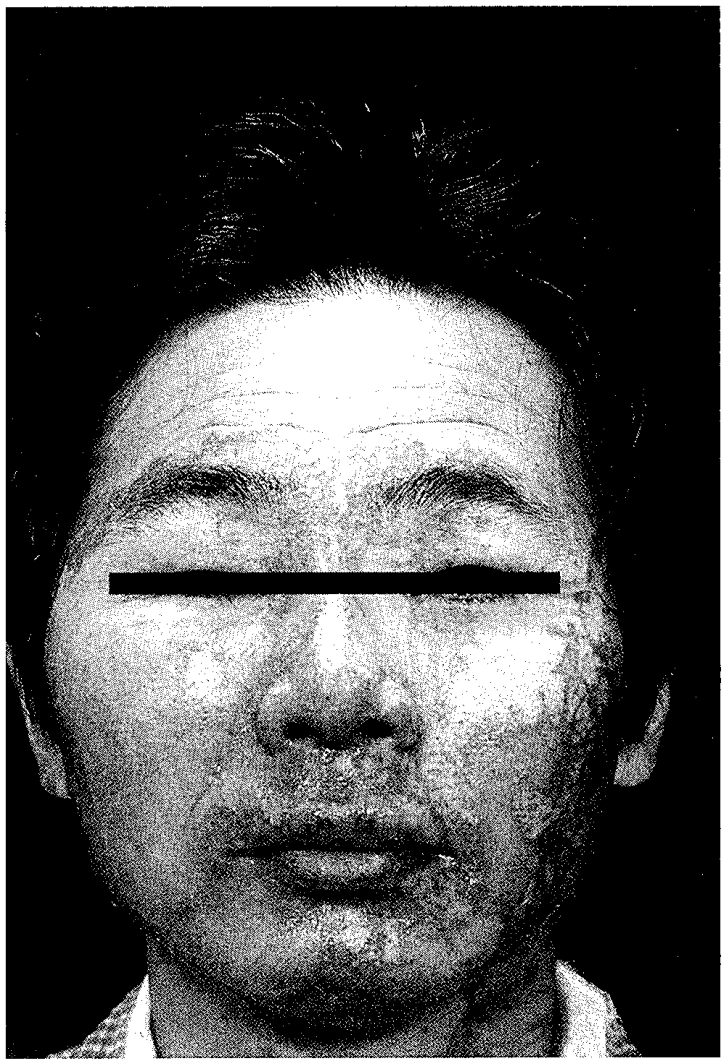

Fig. 1. Case 1, clinical appearance of face at the time of the initial examination: erosion, erythema and yellow crust in dry condition especially in the right auricular region are recognized and bulla is partially formed.

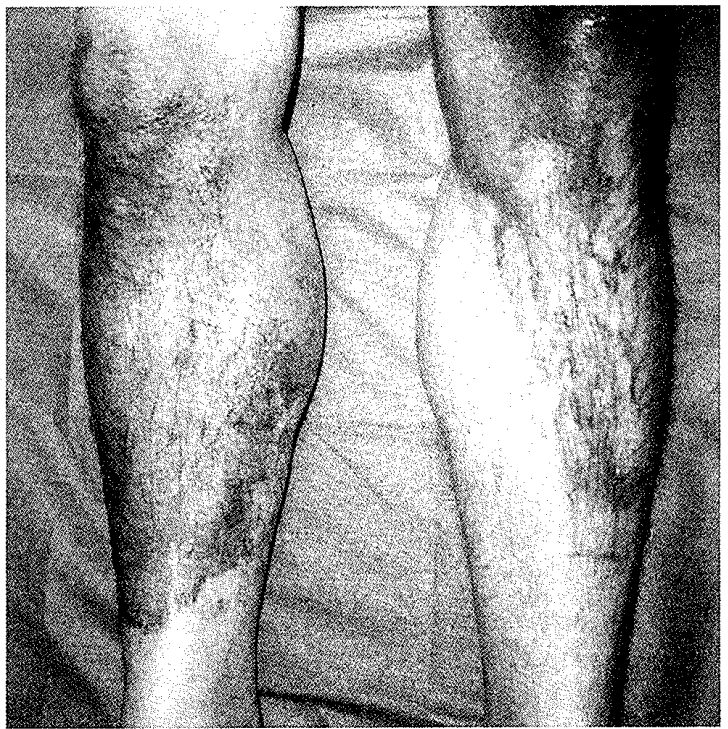

Fig. 2. Case 1, clinical appearance of the legs at the time of the initial examination: erosion, erythema and yellow crust in dry condition are recognized and bulla is partially formed. 
をゴムホースにて希硝酸ライン（60\%硝酸） に導入中, 濾過水側のホース接続部が脱落し, その際外れたホースより希硝酸が流出したの で，ホース内の希硝酸をホースを手繰って抜 き出した後，外れたホースの緊縛を実施した。 再び濾過水を通そうとした時，ゴムホースが 破孔し，内部に残っていた希硝酸が哜出し， 顔面および四肢に希硝酸を浴びた。へルメッ 卜は着用せず，顔面には保護マスクのみ装着 しており，右側頭部に浴びたため，保護マス クと皮表面との隙間より希硝酸が侵入し暴露 されることとなった．顔面のみ約 15 分水で洗 浄した後, 救急車にて当科外来に搬送された. 初診時，顔面から頚部にかけ，特に右耳介に， 黄色調の乾燥した痂皮が付着したびらん, 紅 斑，発赤面を認め，一部は水疮を形成してい た (Fig. 1)。両眼瞼に浮腫を認め, 右眼瞼 ・ 眼球結膜は充血し，両側角膜上皮剥離があっ た。また右上腕から肩甲部㧍よび雨下腿から 大腿前面にも, 顔面と同様の黄色痂皮を付着 したびらん面と紅斑の混在を認めた (Fig. 2)。 な㧍，被災時に着用していた作業衣は変色し たものの損傷はなかった.

入院後, 顔面の病変に対してはステロイド 含有抗生物質軟膏 (クロマイ $\mathrm{P}$ 軟膏 ${ }^{\circledR}$ ), 右 上腕，両下肢の病変に対しては抗生物質軟高 (バラマイシン軟膏 ${ }^{\circledR}$ ) の外用にて保存的治 療を行った. 受傷 2 週間後, びらん面の上皮 化は進んだが，四肢にはいまだ黄色泇皮が固 着し，剥離にて出血が認められたため，四肢 病変部への被覆材を変更した。その後黄色痂 皮が融解した後，痂皮下に潰晹を認めたため， 哚達性の II 度化学熱傷創と判断し, 潰瘍面が 分画されるのを待ち, 受傷26日後, 右肩甲部, 右上腕, 右下腿, 左膝の残存潰瘍部にデブリー ドマン，分層植皮術を施行した。平成 12 年 12 月現在, 顔面化学熱傷後の色素沈着, 瘷痕等 は認めず，四肢の植皮部に色素沈着を残すの みであった。
症例 $2 ： 26$ 歳, 男性.

化学工場勤務（従業員約20名）。

平成 12 年 6 月某日午後 5 時頃, ドラム缶に 濃硫酸を充填中ホースが外れ，ホース内に残 存した濃硫酸を兩前腕部に浴び，工場内医務 室にて約15分冷水洗浄した後，救急車にて当 科外来に搬送された。初診時, 左手関節背側 から前腕屈側，および右前腕屈側に，体表面 積の約 $2 \%$ の浅達性から深達性の II 度化学熱 傷を認めた。また，全身診察時に下着に数力 所の穴を認めたが，皮虐障害は認めなかった。 約 1 カ月間の抗生物質軟高 (バラマイシン軟 膏 $\left.{ }^{\circledR}\right)$ 外用治療にて潰瘍の上皮化は完了した。 平成12年12月時点で，左手関節に肥厚性瘏痕 を認めていたが，機能障害は生じていなかっ た。

\section{考察}

荒尾ら（1998年）は平成 4 年から平成 7 年 にかけて,12施設の協同研究を行い，職業性 皮膚障害の中で災害的皮膚障害は26.8\%で， 化学熱傷は職業性皮膚障害の $1.5 \%$ を占める と報告した [2]。

当教室の山元の調査によれば，平成 2 年度 から平成 6 年度にかけて, 福岡労働基準局管 内で労災申請給付された化学熱傷は34件であ り，酸が原因のものが 9 件 (26.5\%) と原因 別件数では最も多かった。 また，これら労贸 患者の年齢分布をみると34件のうち, 7 件 $(20$. 6\%) が30代，10件 (29.4\%) が40代と中堅, ベテランの化学物質取扱者が多くを占めてい た [3].

硝酸は有機合成，二トロ化合物，爆薬，染 料などの原料として精製されており，工業用 の合成硝酸には $98 \%$ と60\%のものがある [4]. 硝酸の人体への影響としては接触による皮 虐・粘膜・目の激しい薬傷・歯牙腐食，蒸気 の吸入による肺水腫が知られている $[5]$. 硝 酸は皮膚や粘膜の腐食性が強く, 激痛を伴い, 
一般に受傷部の表皮を黄色に変化させる。さ らに作用が続くと，黄褐色の痂皮を形成し， 限局性の深い潰瘍をつくる [1,6-8].この ような人体への作用のため, 硝酸は特定化学 物質等障害予防規則（特化則）の第 3 類物質 に指定されており，製造・取扱作業場の環境 管理に関して，廃液処理装置の設置，漏えい の防止（腐食防止措置, 床の構造, 容器等) などが事業者に義務づけられている $[4,5]$. 特化則の第44条では不浸透性の保護衣, 保護 手袋および保護長靴等の使用を義務付けてい る.

一方, 硫酸は肥料, 爆薬, 染料, 薬品など の原料として精製されて扔り，工業用薬品の 硫酸含有成分は薄硫酸 $60-80 \%$ ，濃硫酸 $90-$ $100 \%$, 希硫酸 $27-50 \%$ とされている [4]. 硫酸の人体に対する作用は, 強力な腐食作用 と全身性中毒作用である。液体，蒸気，ミス トにより呼吸器 - 消化器粘膜, 歯, 眼, 皮膚 に強い刺激作用と化学的熱傷を生じる，皮膚 に接触するとまず激痛を伴って白色，ついで 黄褐色の痂皮を形成する。濃硫酸は脱水作用 が強いので組織は炭化して黒褐色の泇皮とな り，痂皮の剥離後に深い潰瘍をつくる $[1,9$ ， 10].このような人体への作用のため, 硫酸 も特化則の第 3 類物質に指定されている [5]. 症例 1 の働いていた作業現場については, 特化則に従い作業現場近くにシャワーが設置 され，また作業中，作業者は全員保護衣を着 用していた。また両症例とも取り扱っている 酸の危険性については十分な知識があり, 被 酸時の措置もおおむ称適切に行われていたと 考えられる。両患者に被酸時の対応マニュア ルを尋ねたところ, 工場内の救急車を呼ぶと 同時に, シャワーで15分以上洗浄する, 救急 車が早く到着しても洗浄時間は必ず15分以上 とする，ということであった，症例 1 の患者 本人がとった行動は，マニュアル通りであり， 顔面，特に眼の処置を優先したことは，眼の
機能障害, 顔面皮膚の後遺障害がほとんど残 らなかったことからも, 被酸時の処置がおお むね適切であったことがうかがわれる。また 症例 2 も, 両前腕に被酸した直後より備えつ けのシャワーで15分間同部を洗浄しており， この速やかな措置により両手関節部に生じた 皮虐潰瘍は約 1 力月間の保存的治療により治 瘉に至った。両症例とも危険性を熟知し, 定 期的な講習を受けていたために行動できた処 置であり，安全教育の重要性を示している。 産業医への聞き取り調查によると, 両工場で は安全マニュアルも整備され, 各現場で安全 管理の年間計画も立てられ, 実行されていた ようである。

しかしながら，これらの曝露事故について いくつかの問題点を指摘できる。まず，両症 例とも酸の充填中にホースが外れるという突 発事故による曝露であり，ホースの連結部あ るいはホースと注入口の固定が確実になされ ていたか，作業上のミスはなかったか，が問 題となる [11]。ホースやその連結部につい ては，その後産業医の指導のもと速やかに厳 重な点検がなされたとのことであった。また 症例 1 については，やはり作業のベテランで あるという慣れから，ホースの脱着操作に対 する注意が十分になされなかった可能性もあ り，さらにホースが破裂するという突発事態 が加わって事故が起こったものと思われる. ベテランに対する繰り返しの再教育と，突発 事故の事例を検討し，ベテランも含め突発事 態が常に起こりうることについての注意を哃 起する必要がある。

次に，水による洗浄処置について検討して みると, 症例 1 では顔面の, 特に眼に対する 損傷を最も重篤であると自己判断し，全身に シャワーを浴びることなく, 洗顔・洗眼のみ を行った。この措置により，角膜・顔面の皮 䖉の損傷は保存的加療により治癒したが, 右 上腕，両下腿の損傷は II - II度の化学熱傷に 
陥った。これまでにも，時々手足に少量被酸 することはあったが，ごく軽い損傷ですんで いた経験も油断につながり，四肢の洗浄をし なかった理由としてあげられる。四肢の被酸 部位も早急に気付き，洗浄していれば，植皮 術まで行わずにすんだ可能性がある．特に硝 酸の場合，繊維への浸透速度が水に比べ早い と言われており [12]，早期に，被酸した衣 服を脱ぐことが勧められる。症例 2 は両上肢 を着衣のまま洗浄しており, 診察時も作業衣 が濡れていた，硫酸の場合，作業衣の被酸部 位に孔があくため被酸箇所が明確であると思 われる。体幹，下肢に被酸はないと本人は話 していたが，念のため全身の診察を行ったと ころ，下着に数力所孔があいており，作業衣 からの滲み込みがあったものと考えられる。 幸いこれらの部位の皮膚障害はなかったが, 身体の思わぬ部位に曝露されうる可能性を示 唆する所見と思われる。これらの事例より， 被酸の部位や大小によらず保護衣を脱き，被 酸した主な部位のみの洗浄だけでなく，全身 シャワーを浴びるという項目を，強酸受傷時 のマニュアルに付け加えることを勧めたい.

第三に保護マスクについてであるが，症例 1 では右側頭部より硝酸を浴びたため，右耳
介に最も多くを浴び，さらにマスクの隙間か ら硝酸が侵入し, 主に右顔面, 特に眼の周囲に 化学熱傷を受傷する結果となった。このこと は，保護マスクの改良あるいはへルメットも しくは頭部保護具装着の必要性を示唆してい ると思われる，逆に防護マスクに隙間があっ た場合，その隙間から侵入した酸に曝露する と，酸が外方へ排出せずに皮膚障害をさらに 悪化させる可能性もある。

最後に診療を行った側の反省点として，症 例 1 の四肢曝露部の皮虐病変部を，黄色の痂 皮の付着のみと過小評価し，媣達性の潰瘍の 存在に気づかなかった点は，反省の余地があ る。硝酸による化学熱傷では，前述したよう に潰瘍面に黄褐色の泇皮を形成することが多 い. 従って，硝酸による化学熱傷を診察する 臨床医は，これを単なる感染性滲出性泇皮と 混同することなく，その下に深達性潰瘍が存 在する可能性を常に念頭に置くべきである。

事故防止のため，より質の高い安全対策と 安全教育が望まれる。また，臨床医からも産 業医に事故防止あるいは被災時の対処法につ いて提言することでより良い作業環境を招来 しうると思われる。今後の産業医と臨床医の 連携関係の発展を望みたい。

\section{引用 文 献}

1. 堀内信之 (1987)：化学熱傷. 産業皮膚科学（臨床産業医学全書 4).（永井隆吉, 野村 茂, 編)。医歯薬出版，東京 pp 168-173

2. 荒尾龍喜, 熱海正明, 富澤尊儀（1998）：職業性皮膚障害についての統計的観察。日本災害 医学会会誌 $46 ： 343-353$

3.山元修 (1996)：化学熱傷（シンポジゥム：職業性皮䖉障害(2))。マルホ皮虐科セミナー放 送内容集 $125: 35-38$

4. 松井寿夫 (1993)：強酸性物質取扱業務の健康管理. 化学物質取扱業務の健康管理.（和田 攻, 編). 産業医学振興財団, 東京 pp 528-546

5. 中央労働災害防止協会（編）（1999）：化学物質の危険·有害便覧. 平成11年版.中央労働 災害防止協会，東京 pp 508-509, pp 952-953 
6. 杉内利栄子, 高橋和宏（1996）：濃硝酸による顔面の化学熱傷の 1 例. 皮膚臨床 38 ：382383

7. Cavigneaux A (1989): Nitric acid and nitrates. In: Encyclopaedia of Occupational Health and Safety. 3 rd ed. (Parmeggiani L, ed). International Labour Organization, Geneva pp 14431445

8. Zenz C (1994): Nitric acid. In: Occupational Medicine. 3 rd ed. (Zenz C, ed). Mosby-Year Book, Inc., St. Louis pp 667-668

9. Alelsieva Z (1989) : Sulphuric acid. In: Encyclopaedia of Occupational Health and Safety. $3 \mathrm{rd}$ ed. (Parmeggiani L, ed). International Labour Organization, Geneva pp 2124-2126

10. James J (1994) : Sulfuric acid. In: Occupational Medicine. 3 rd ed. (Zenz C, ed). MosbyYear Book, Inc., St. Louis pp 670-672

11. 小泉晶夫他（1995）：硫酸製造工業プラントにおけるいわゆる製錬所病の事例検討。産業医 学ジャーナル 18：41-47

12. 吉田康久, 岩崎 錦（1975）：酸作業における作業衣の保護効果. 産業医学 17：155-164 
Occupationally Induced Nitric Acid and Sulfuric Acid Burns:

An Analysis of 2 Patients from the Aspect of Occupational Health

\author{
Hiroshi Orimo, Osamu Yamamoto, Miwa Kobayashi \& Hiroshi Yasuda \\ Department of Dermatology, School of Medicine, \\ University of Occupational and Environmental Health, Japan.
}

Yahatanishi-ku, Kitakyushu 807-8555, Japan

Abstract: We report two patients who suffered from acid burns while working in chemical factories. Case 1 : a 44-year-old man who received burn induced by nitric acid on the face and extremities. Despite his protecting facial mask, he was exposed to nitric acid on his face through a gap between the mask and skin surface. Nitric acid was also sprinkled on his scalp which was not covered by a helmet or a protecting device. In addition, he suffered from acid burn on the right scapular region, the right upper arm, and the lower extremities through the work clothes. Case 2: a 26-year-old man who suffered from sulfuric acid burn on the forearms. Both patients were accidentally exposed to acids while they filled tanks with the acids through a hose. Following the manual of the factories, they washed the exposed skin with water for more than 15 minutes after the exposure. Although they recovered without any serious sequel, there remained partial deep tissue destruction of the skin. We reviewed these two cases from the aspect of industrial medicine, and proposed the following three points for improvement in the workplace to prevent accidental acid burns. 1) re-education or enlightenment activities for the well-experienced workers to avoid negligence to the danger of strong acid. 2) recommendation to take a complete shower to avoid overlooking of unaware acid injury. 3 ) improvement in the protecting facial mask. In addition, clinicians who examine acid-burn patients should not pass over the presence of deep ulcers lying behind the thick crust on the injured area.

Key words: nitric acid burn, sulfuric acid burn, occupational skin disease.

J UOEH $23(1): 69-75(2001)$ 